\title{
WOMEN IN THE IDENTITY CRISIS OF FEMINISM; A CRITICAL ANALYSIS ON GENDER MOVEMENT BASED ON ISLAMIC PSYCHOLOGY PERSPECTIVE
}

\author{
Septi Gumiandari \\ Fakutlas Tarbiyah dan Ilmu Keguruan, LAIN Syekh Nurjati, septigumiandari@gmail.com \\ Ilman Nafi'a \\ Fakutlas Tarbiyah dan Ilmu Keguruan, LAIN Syekh Nurjati, ilmancirebon72@gmail.com
}

\begin{tabular}{|c|c|c|}
\hline Diterima: 24 Januari 2019 & Direvisi :15 Mei 2019 & Diterbitkan: 30 Juni 2019 \\
\hline
\end{tabular}

\begin{abstract}
This paper attempted to analyze critically the women's movement that had been developing so far and tried to offer the ideology of the gender movement based on the values of humanism of Islamic Psychology. This study used a qualitative methodology with a literature approach. The results showed that (1) the male clone tendency in the women's movement had actually been predicted by various parties, including by the female activists. Because of the obsession to equalize the active role of women as equal to men, the women's movement was trapped in standardizing themselves with male masculinity figures. On one hand, they rejected male domination on women, but on the other hand the ambitions of their movements are directed towards seizing the dominant patriarchal system and violating it under the authority of women. Even though Islam places women in the frame of proportionally optimistic rational roles. That is, Islam does not make women fully pretend to be 'backward' entities so that it does not allow them to gain enlightenment and Islam rejects thoughts that are too optimistic to position 'front' women as the sole determinant of their lives and must be above men. Both of these views bave reduced women to fall into the destruction or glorification of human quality by ignoring the greatness and power of Sunnatullah over the surrounding conditions; (2) According to the values of bumanism of Islamic Psychology, the ideology of the gender movement should depart from the needs and be based on a) Women's selfactualization rather than self-exploitation; b) Women's Active participation rather than their mobilization and domestication. (c) Partnership rather than rivalism.
\end{abstract}

Keywords: Gender Movement, Islamic Psychology, and Identity Crisis.

\begin{abstract}
Abstrak
Penelitian ini menelaah secara kritis gerakan perempuan yang selama ini berkembang, serta menawarkan idiologi gerakan gender yang berbasis pada nilai-nilai humanisme Psikologi Islam. Penelitian ini menggunakan metodologi kualitatif dengan pendekatan literatur. Hasil penelitian menunjukkan bahwa (1) Kecenderungan male clone (tiruan laki-laki) dalam gerakan perempuan sesungguhnya telah diprediksikan oleh berbagai pihak, termasuk oleh para aktifis perempuan. Karena obsesi untuk mensejajarkan peran aktif perempuan setara dengan laki-laki, maka tak jarang gerakan perempuan terjebak pada standar dan norma-norma maskulinitas yang dikritiknya sendiri. Di satu sisi, mereka menolak dominasi laki-laki atas perempuan, tetapi di sisi lain ambisi gerakannya justru diarahkan untuk merebut sistem dominatif patriarkhi dan melanggarkannya di bawah kekuasaan perempuan. Padahal Islam menempatkan perempuan dalam bingkai peran rasional yang optimistik proporsional. Artinya, Islam tidak menjadikan perempuan berpretensi sepenuhnya sebagai entitas 'terbelakang' sehingga tak memungkinkannya memperoleh pencerahan dan Islampun menolak pemikiran yang terlampau optimistik memposisikan perempuan 'terdepan' sebagai penentu tunggal bagi kehidupannya dan harus berada di atas laki-laki. Kedua pandangan ini telah mereduksi
\end{abstract}


perempuan untuk jatuh pada pengkerdilan ataupun pengagungan kualitas insani dengan mengabaikan kebesaran dan kekuasaan sunnatullah atas kondisi sekitarnya; (2) Format gerakan pemberdayaan perempuan ke depan hendaknya berangkat dari kebutuhan dan didasarkan pada a) kiat aktualisasi diri bukan eksploitasi diri; b) Partisipasi aktif bukan mobilisasi dan domestikasi. (c) Patnership bukan rivalisme.

Kata Kunci: Gerakan Gender, Psikologi Islam and Krisis Identitas.

\section{Introduction}

Francis Herper, a participant at the Worlds Congress of Representative Women meeting in Chicago, ever said that "In the hands of women there is an opportunity --if they use it or abuse it, both positive and negative- to spread the way for the emergence of new civilizations in the future." ${ }^{1}$ After almost a hundred years later, whether intentionally or not, Francis Herper's predictions showed the face of truth. A book of Mega Trend 2000 written by a couple Naisbitt (1989) reinforced the preposition, that "the era of the grandeur of women will gain momentum in the future."

Hopes for the role of women above began to be proven by interesting symptoms since the end of the next decade when many women are manifested in their role. The bargaining power of women in occupying strategic posts increasingly shows an increase over time, even shocking phenomena occur in the country, women's contributions and activities are slowly entering the public area which from the beginning was almost neglected. Women have risen from their long sleep and started to control the public sphere, so that its position later, no longer as a konco wingking (partner who is always behind men), but began to align themselves in acting in the public sector.

In the Indonesian context, in the past ten years in Indonesia many female politicians

${ }^{1}$ Bem, Sandra Lipsits, (1993), The lenses of Gender. New Haven: Yale University Press, 39.

2 Naisbitt, John \& Patricia Aburdence, (1990). Megatrends 2000. New York: Avon Books, 294. have graced the political arena, on the other hand, even large crimes where women as perpetrators or victims show a relatively high level of participation. ${ }^{3}$ This reality is possible because, in order to maximize the reduction of gender inequality, contemporary feminists generally suggest the need for a truly revolutionary approach. Efforts to free themselves from biological determinism and its social role are forced on women, without realizing they tend to be over rational and this turns out to present new problems in the women's body itself. Why not, because the femininity side then becomes a separate commodity and is a trade mark of a woman. In these conditions, many contemporary feminist theories are unable to adequately explain the implications of the relationship between men and women without normative boundaries which give rise to a variety of social pathologies. This approach epistemologically continues to be applied, so the threat of a feminine identity crisis cannot be avoided.

This paper attempted to analyze critically the women's movement that had been developing so far and at the end of the paper, the author tried to offer the ideology of the gender movement based on the values of humanism of Islamic Psychology. This is very important to be explored, given the prepositions expressed by Sachiko Murata in his work The tao of Islam, that "A feminist movement can only be accepted by society and has a positive result, insofar as it is not

3 Widyaningsih, Wahyuni, (2001), Feminisme, ekofeminisme dan Islam Mistik in Jawa Pos. 20 Januari 
uprooted from the sociocultural roots that surround it." ${ }^{4}$

\section{Methods}

This research used qualitative methodology with a literature approach. Since this study explored about "Women In The Identity Crisis Of Feminism; A Critical Analysis On Gender Movement Based On Islamic Psychology Perspective," the first and foremost sources are all literatures including books, journals, writing talking about Psychology, Islam and gender movements. As much as possible data is attempted to be obtained from primary sources, but it does not rule out the retrieval of data from secondary sources. To obtain an accurate interpretation about the content of the concept of women movements, the author used Gadamer's Hermeunetic approach. While in analyzing the data, the researcher used content analysis.

\section{The Trap of Eco-Masculinism in the Women's Movement}

In the view of Nurcholis Madjis's (1996) thinking, Indonesian women's movement emerged prominently in today's intellectual discourse departing from two frames of thought; First, discourse that is born in a legitimate, authentic and true manner. It means that it really arises from a pure desire to enlighten the role of women into the future). Second, it is a reaction to the oppression of women who sometimes feel emotional, apologetic, ideological, and not often subjective. Nevertheless, Madjid continued, from the cracks of the movement sometimes it appears original reflection and creative thinking. ${ }^{5}$

${ }^{4}$ Murata, Sachiko, (1999), The Tao of Islam; Kitab Rujukan tentang relasi Gender in Kosmologi dan Teologi Islam. Bandung: Mizan, 24.

5 Madjid, Nurcholish, (1996), Islam agama Kebudayaan. Jakarta: Paramadina, 32.
Apart from an agreement or disagreement with the above thoughts, but reality has certainly said that the condition of the success of women from their substance content is a new dimension in the sexual division of labor discourse. This new dimension revolves around the problem of shifting the ratio of the level of participation with truly reasonable considerations in which the jargon of masculinity does not always appear as idioms to realize a new civilization. This is proven, along with the structural functional teaching that the development paradigm has brought about social change, institutions, and traditional value systems which in turn force women to participate in the issue.

In the context of developmentalism, women assume philosophically that they are present as rational beings, like men. They agreed that the foundation of its success was rooted more in the demands of freedom and equality, when the hegemony of social buildings ended with the separation of the public and private worlds. Although they are not very interested in looking for a positive correlation between the structure and system of sexual division of labor, the theme of rationality is an interesting challenge for improving the quality of participation in the future. Carol Gillian in her book "In different voice" (1982) argues that women are moral beings who always want to socialize, so they are more dominant to participate through mutual empowerment patterns in their unity with the central network structure. ${ }^{6}$ In other words, the manifestation of women's participation concentrates more on the internalization of the value of success and awareness efforts from the sources of backwardness that rotate with gender injustice as excesses of traditional values that they hold firmly before.

${ }^{6}$ Gillian, Carol, (1982), In a Different Voice. Cambridge: Harvard University, 21. 
Behind the symptoms of strengthening women's bargaining power and attributes of success, many social critics claim that it is all symbolic success and has not achieved results at all. This is very potential if the success is more interpreted partially and just to be proud. Margaret Mischelich, a German psychoanalysis in the book "Die Zukunfst Ist Eseiblich" warned that the success of women now is substantially not at all meaning as long as the person concerned continues to preserve the paradigm of masculinity. She emphasized that the existence of a process of exchange of value from the sense of femininity to masculinity is a blunder that threatens its existence. ${ }^{7}$ This can be understood because the values of masculinity which contain lust for power, exploitation, competing, domination, and oppression are truly strange characteristics for women and not appropriate to emulate in the movement of women towards success.

Reality tells a different phenomenon, the women's movement is still dominated by eco-masculine thinking. This trend can be seen from the strengthening of the patterns of thought and movement of women who force themselves to collaborate with the ideological spirit of bourgeois liberalism and radical Marxism. This phenomenon was seen in the works of feminist activists in the last decade, and ironically it was justified by Muslim activists. Just say, for example, the second sex (1948) by Simonede Beauvoir, which states that feminine norms inherent in women, such as caregivers, nurturers, passivity, and recipients characteristics are not the nature of women themselves, but rather as cultured traits by the patriarchal system to perpetuate the project of oppression of men over women. ${ }^{8}$

This thought was basically influenced by existentialism philosophy which was

${ }^{7}$ Kristeva, Julia, (1990), Thingking Fragmentt, Psychoanalysis, Feminism and Posmo dernism in the contemporary West. USA: University California Press, 25.

${ }^{8}$ Ibid., 25. developed mainly by a famous 20th century philosopher from France, Jean Paul Sarte. They believe that humans do not have what is called innate nature, which is detached from nature. Humans existence depends entirely on how they create their own essence. In other words, what is called human essence is basically socially created, which depends on the environment in which it is located.

Departing from this existentialist frame of mind, the effort to liberate itself from the oppressive patriarchal system needs to be fought for freedom and equality of rights for women to be equal to men; both in the social, economic and political fields. This is the driving force for women's activist steps to flock into the masculine world and act like men.

At the individual level, this movement tries to apply feminism through the concept of androgyny education which aims to eliminate the differences in gender stereotypes between men and women carried out especially in early childhood. This education requires children to be raised in a gender free environment, for example giving toys to girls and puppets to boys. ${ }^{10}$ Unfortunately this concept ignores the psychological analysis of Classical Freudians with its oedipus complex, that boys through their sexual libido power want to imitate the father's masculine behavior in dealing with the opposite sex. Even in extreme assumptions, the concept of androgyny education according to Kenneth Kammeyer in the book "marriage and family foundation for personal decisions," (1987), has the potential to form an adult personality that is ineffective and difficult to adapt to an environment or culture that does have gender stereotypes. ${ }^{11}$

${ }^{9}$ Megawangi, Sekapur Sirih in The Tao of Islam, 7. ${ }^{10}$ Ibid, 8.

${ }^{11}$ Hewlett, Sylvia Ann, (1992), When The Bough Breaks; The Cost of Neglecting our Children. Boston: Beacon Press, 12. 
More than that, in order to free themselves from oppression, and male hegemony, the women's movement unwittingly tends to be over rational and reactive, so what Madjid assumed was assumed at the beginning, movements and thoughts that present various legitimacy norms of life that are so emotionally reactive, which was almost unthinkable before. For example, non-children and non-marriage movements that began to live among female activists. Both are seen as the beginning of slavery and the emergence of female domestication. ${ }^{12}$ Not to mention, the increasing number of divorce cases that have surfaced with various reasons for domestic violence that are sometimes rationalized in such a way as to legitimize all the behavior of husbands who are considered out of the corridor of the values of equality and justice.

This is tragic. Why not, because in these conditions, the women's movement is no more like what is claimed by conservatives as a movement that will shake the stability and harmony of the household. In connection with this phenomenon, many contemporary feminist theories are unable to explain and provide adequate solutions regarding the implications of the relationship between men and women without normative limitations that present a variety of social pathologies. The problems that occur among women activists who are too far out are essentially a false revolution, because without the basis of psychological, emotional and religious independence, what emerges in the discourse above is fragile independence.

This approach has never uprooted feminism as a branch of social science that is so personal and comprehensive, where women appear as objects as well as subjects, but this condition can slowly affect the emergence of assumptions of women's movements that are too monolithic, and unable to represent

${ }^{12}$ Hewlett, When The Bough Breaks, 12. women's participation in different contexts and perspectives. So the theme of the movement becomes no longer value free. Even though from the beginning, the movement wanted to provide universal awareness for women that the traditional role placed them in an unfavorable position, namely the female subordination, but unfortunately, this view then biased the relative assessment on the standards of women's success that refer to changes in behavior with or without offending whether feminine nature is nature or a social building that shapes it. Especially by linking it with the problem of marriage, children and divorce.

It can be understood, that unconsciously, the women's movement above has actually been trapped in the standards and norms of masculinity which they criticized themselves. On the one hand, they reject male domination of women, but on the other hand the ambitions of their movements are directed towards seizing the dominant patriarchal system and violating it under the authority of women.

As a result, the thesis of masculinity which is supported by the patriarchal system and the antithesis of the feminism movement that has the pattern of eco-masculinism does not give any meaning to the face of modern civilization which is increasingly dominating, exploitative and not humanizing humans. Natural damage, pollution, crime, social disintegration and political conflicts remain familiar in modern human life. On the other hand, the position of women themselves remains the object of a three-tier exploitation system; First, at the global level, as the majority of peripheral people, women will always be victims of gaps and injustices in the international system. Second, at the level of production, as the largest group in the lower layers and stratification of industrial work, women will be the first victims of the gap in the pattern of industrial capitalist relations. Third, at the societal level, women must face 
unfair treatment of gender structures and ideologies that develop into myths. ${ }^{13}$

\section{Initiating the Women's Movement}

The male clone tendency in the women's movement had actually been predicted by various parties, including by the female activists themselves. Because of the obsession to equalize the active role of women as equal to men, the women's movement often fell and was trapped in standardizing themselves with male masculinity figures; both physically and non-physically. For this reason, various efforts that have been rolled out in order to eliminate the birth of negative excesses from the wave of social change presented by the women's movement in their participation in the public sphere, have actually been, and have not been ceaseless, carried out. Among them is the process of reversing discourse as has been raised by Suzanne Gordon through her book Prisoners of Men's Dreams (1991). ${ }^{14}$

In its perspective, the women's movement should be directed from the paradigm of eco-masculinism which promotes masculine quality and biological cultural equality towards advancing feminine qualities and maximizing natural differences between women and men. If feminine quality was previously considered inferior, now on the contrary the superior image was raised for feminine quality. This movement was later more popular with the term eco-feminism, a word which departed from the philosophy of eco-philosophy or ecosophy and was popularized the first time by Francise d'Eaubonne. Unlike Sartre's existential philosophy, this philosophy assumes that

13 Ida, Laode, (2001), Gerakan Wanita dan Dilema Budaya Lokal in Jawa Pos, 5 September.

${ }^{14}$ Gordon, Suzanne, (1991), Prisoners of Men's Dream; Striking out for a New Feminine Future. Bosto: Little, Brown and Company, 22. human beings have an eternal essence, namely consciousness. ${ }^{15}$

According to the eco-feminism paradigm, the crisis that befell modern civilization today stems from the human tendency that too adores "the father god. Quality of life is more measured by the characteristics of power, active, separate, independent and dominant. Because modern civilization has separated itself from humans, so that the trinkets of life become fragmented, separate, and atomized. Humans grow into competing egos, who view fellow human beings as something totally independent of each other. Human relations with the natural environment also become so isolated from each other, mere objects and subjects. As Irene Diamond said, the behavior of masculinity has resulted in the process of mastering and exploiting nature by humans blindly. ${ }^{16}$

Therefore, to overcome this modern civilization crisis, there is no other way except through attempts at reversing discourse, by promoting worship of "the mather God," who is close, love, recipient and carer, or in the language of Bill Devall and George Sessions (1985), this movement basically wants to be directed at a process of awareness to see humanity as an existence that is familiar and united with the universe. ${ }^{17}$

As a discourse, this effort does seem to have a result, but it has not been able to eliminate global humanitarian concerns as mentioned above. Moreover, the process of reversing the discourse from eco-masculinism towards eco-feminism seems to be engineered theoretically and does not touch the praxis of the problem of femininity. Because with the approval of the term mapping 'feminismmasculinism, metaphysically has created a

15 Ibid., 22.

${ }^{16}$ Diamond, Irene dan Gloria Leman Orenstein (ed.) (1990), Reweaving the world; the emergence of Ecofeminism. San Francisco: Sierra Club Books, 5.

${ }^{17}$ Zimmerman, Deep Ecology, 17 
dichotomy of subjects (men) against objects (women) or vice versa. ${ }^{18}$ And such a culture will never solve the problem of masculinity and femininity unless we take another approach which is to get out of essential thinking using symbols to find legitimacy for the meaning of cultural dynamics.

Therefore, efforts to launch a strategic movement for women must always heed various aspects of the meaning of human life, and are not directed to categorize men and women in opposition stereotypes which are opposites, moreover if it is attempted to favor one another then turn to colonize each other, but to emancipate culture in an equal relationship towards just humanity. This is because both men and women are products of their respective cultures.

In other words, the format of women's strategic movements should be directed as an effort to humanize women as exclusive beings as well as men in carrying out the mandate of caliph fi al-Ardl (Surah 33: 72), have broad freedom and must not be forced,even though in matters of religion, especially in its sociocultural life (Qur'an 2: 256). Women and men both get the gift of knowledge that makes angels bow down (QS. 2: 31-34) and so on. From this it can be understood that, women in the lap of religious norms are not passive beings who are powerless to be positioned as the second sex after men, nor are they a truly sovereign and over rational creatures in navigating their lives without dependence on the surrounding environment, including their opposite sex.

In the context of women's empowerment, the theological meaning of the term Khalifah fi al-Ardl above implies that women basically have human qualities as part of their biological nature that must be found by themselves, actualized and developed with various creativity that motivates their desire to

${ }^{18}$ Kristeva, Thingking Fragmentt..., 25. achieve meaningfulness life. Because this quality of self is only a handful of manifestations of the greatness of God that always requires guidance from the moral messages of his prophets and apostles, the ability to achieve it will depend greatly on various factors; both education, socio-culture, and the scale of meaning and life partner. ${ }^{19}$ For that reason, it can be said that humans will always need guidance and depend on entities outside themselves in their success.

From the explanation above, it can be concluded that excessive rationalism in looking at women as an attribute in carrying out success for the empowerment of women today will certainly have an impact on suppressing or deification of the quantitative problem of women who will tend to sacrifice the feminine identity itself. It will also obscure the feminine and masculine territory for women. What is clear, we all certainly do not want the feminine thinking ability to be a sacrifice of success for themselves. Because the concept of fitrah described by Islamic ideology is diametrically different, even contrary to the conception of Western feminism in looking at women's potential. Islam places women in the frame of proportionally optimistic rational roles. In other words, Islam does not make women fully pretend to be 'backward' entities so that it does not allow them to gain enlightenment and Islam rejects thoughts that are too optimistic to position 'front' women as the sole determinant of their lives and must be above men. Both of these views have reduced women to fall into the destruction or glorification of human quality by ignoring the greatness and power of Sunnatullah over the surrounding conditions.

For this reason, the structural and functional redefinition of women's movements in this context is absolutely necessary. The process of defining the movement is only a

19 Shihab, M. Quraisy, (2000), Gender; Pembagian Kerja Pria Wanita in Jawapos; 12. Desember 
reflection and is not something essential for women as individuals or collectively. Because this process will not be conducive, if it is not realized there is a connection between each problem with the existing context and logic. Not to mention, foresight in analyzing the time span that cannot be cut off continuity between the past, the present and the future, all of which are often reduced in disproportionate logical consequences.

Departing from the intended thought and to facilitate the mapping of women's problems, there are at least a number of things that should be put forward to the bargaining power of women in moving:

\section{Self Actualization and not Self Exploitation.}

The pattern of women's movements in the future should depart from their needs and be based on self-actualization rather than selfexploitation. ${ }^{20}$ Self-actualization involves an autonomous condition to determine where they will actualize themselves, outside or inside the house. Self-actualization also provides space for the capacity of bargaining positions where they can be fully involved in the decision-making process for everything that concerns themselves, both in the domestic and public sectors.

At the theological level, this concept of actualization has a lot of harmony with the concepts of Islamic Psychology. True Caliphate in Islamic perspective, actually depends entirely on the totality of the integrity of the human personality; both men and women in determining their principles and social roles. This is in accordance with the word of God: "Surely Allah will not waste the deeds of someone who works for both men and women" (al-Qur'an, 3: 195). This verse shows that women besides having the ability to

20 Dzuhayatin, Sri Ruhaini, (1996), Mencari Format Gerakan Strategis Perempuan Indonesia; Sebuah catatan awal in Seminar Nasional: SEMA Adab IAIN Sunan Ampel Surabaya, 30 Januari know the secrets of nature, are also required to actualize themselves in practicing this knowledge, besides that, this verse also states that there is no difference in the potential of knowledge and work between the sexes, and there is no mapping of the roles that must be taken, whether public or domestic, both of which can spur the level of self-actualization of women, where one is not superior or more backward, insofar as women are able to empower their potential. Work can be done anywhere, at home or outside the home, as long as there is constructive creativity for global humanitarian empowerment. ${ }^{21}$

Conversely, the concept of selfexploitation has reflected an unequal relationship which in turn will lead to relationships that benefit those who have access to power; both political, cultural and economic. Exploitation does not always have to be understood as physical and psychological oppression as experienced by workers but also in fields where a person, consciously or unconsciously, has negated the control capacity of her own body, both physically, psychologically and sexually. In this case, including in the field of our political economy, which always treats cultural discounts for women.

In this case, women are cornered in a consumptive position at the elite level by stimulating their greed on luxury goods and cultivating their own admiration by polishing and even giving up their bodies being tortured by various diet advertisements and plastic surgery. From this it is understandable, that exploitative actions on women themselves to play an active role, will only lead them as mere consumers who are manipulated to follow the ideology of the producers. In this context, women are placed as passive subjects, if not said objects in the process of accumulation of wealth, both nationally and internationally.

\footnotetext{
${ }^{21}$ Shihab, Jawapos, 5.
} 
Reality tells us that there is a backflow of culture of consumerism, which is no longer the consumer who determines their needs but it is the producers who dictate the needs of consumers. Thus, without realizing it, women at the workers level with the reason of emancipation in their public roles are pushed by economic demands, dictated by market needs and national economic policies, to give up their bodies and souls by the workforce who do not consider their femininity. As creatures, they are very vulnerable to termination of employment and sexual abuse just because they are women. ${ }^{22}$ The world of work has not fully taken into account what is in their heads, but rather requires a part of the body that can excite its business clients. The use of almost naked models demonstrating goods that sometimes have no relevance to the exploitation of their bodies is an agenda that needs to be resolved. For this reason, the Feminist Musilim Psychology agenda in the future is not only focused on the ideological level about the nature and normative criticism of wisdom which is often unilaterally played by men, but what is needed is multidisciplinary analysis and cross-sectoral solutions in dealing with the complexity of the problems above.

\section{Active Participation Rather than Mobilization and} Domestication

The issue of emancipation with equality of learning opportunities championed by liberal feminists, including Kartini or anyone who has a concern for the importance of higher education for women in the course of their history has now turned into mobilization and domestication of women. After the free market economy globalized, education intended to instill independence and bargaining capacity for the social role of women has transformed into training places for career women who reduce them to the

22 Yasanti, (1995). Lika liku Burub Perempuan. Yogyakarta: Pustaka pelajar, 23. driving force of the country's economy. The free market ideology considers that women in the home as reserved laborers will continue to burden the country's economy and therefore must be pushed out of the home. ${ }^{23}$

In this condition, the role of women in the domestic sector or "housewives" is seen as meaningless. This fact is ironically also supported by economic statistics that do not include them as productive segments. For this reason, mothers are mobilized in such a way, with 'emancipation' reasons to go out and go with the flow that might even condition it to play a role not as maximal as the previous role, in the house. Freedom to choose a role has been put in place by global culture which underestimates their role in the home. Even though the quality of any role played by women, both in the public sphere (as a career woman) or in the domestic sphere (housewife), as long as they are able to devote their quality and quantity to work well, both of them contribute valuable to human empowerment completely.

But unfortunately, domestication has ideology in all domains. In the domestic sphere, throughout the course of history, patriarchal culture and the global economic system still place salary recipients as people who have control capacity for their opponents, and in line with that, the culture that views superior men from women has made housewives in a subordinate position in the authority of the husband. ${ }^{24}$ In the household, because women are seen as second beings, if conditions are compelling, men are given more priority in the fields of health, education and other fields. ${ }^{25}$

23 Ibid., 23

24 Thomsen, Veronika B., (1988), Why do Housewives Continue to be created in the third world too? Dalam Women the last Colony, Maria Mies (ed.) (London Zet books Ltd.), 159-166.

${ }^{25}$ Fakih, Mansour, (1996), Analisis Gender dan Transformasi Sosial. Yogyakarta: Pustaka Pelajar, 19. 
Whereas in the public sphere, the domesticization of women basically can be clearly observed if we analyze economic political policies that are rolled by the government. The legacy of patriarchal ideology that is so thick in the mindset of policy holders has spread the way for women to work outside the home due to economic considerations. When women are actively involved in their public sector, at the same time, national cultural ideologies bind their activities by proclaiming "the Five Tasks of women" which as a whole is an over-domestication effort. Tragically, the double burden caused by these two opposite conditions is neatly and elegantly wrapped up in the name "Women's Double Role." On the one hand, women are required to maintain their traditional role, while on the other hand, women are expected to succeed in their public roles.

This dual role has cornered women in the process of defining their structural roles to become a prolonged dilemma. The failure of a husband's career is often seen as a failure of a woman to act as a wife. As a husband's faithful companion, women must bear the bureaucratic sins of their husbands. This position precisely sharpens the subordinate position structurally because its existence is very much determined by the position of the husband in the office not on the basis of the individual capacity of the woman herself. ${ }^{26}$ On contrary, if they fail in a career in the public sector, the accusation is directed at themselves as women, who have never been able to match men. The legitimacy of religion also turns out to strengthen the marginalization of women. Because women get half inheritance from men and witnesses in economic matters (and not on other issues), then they are legitimate to be seen as inferior, so that in the public sector they are ignored in

${ }^{26}$ Sullivan, Norma, (1991), Gender and Politics in Indonesia in Why Gender Matter in Southeast Asian Politics, Maila Stivens (ed.) Melbourne: Monash University Press, 34. the promotion of strategic positions. And there are many other examples. Women are faced with more complex problems.

For this reason, is it enough to punish them with various accusations against nature and establish a prohibited fatwa for their public role because of the existence of madharat? Or should then women be encouraged to re-enter the house, so that they are again conditioned on our cultural and economic system that ratifies the husband's salary as a patriach in his household, ${ }^{27}$ then we justify it with our religious perspective which is not necessarily free from our cultural views? ? $^{28}$ This kind of psychological release never completes everything. Instead, it will condition women in a position that is completely confused and not empowering.

Departing from the reality above, women should be more careful in actively participating in domestic or public matters. With more emphasis on proportionalism and professionalism in both domains, it will strengthen women's steps in showing their true identity. In such a constellation, the upcoming women's movement should be directed at empowerment and movement at the level of discourse and thought and increasing active participation in the struggle for strategic access without being mobilized by any interest, starting from the pure desire of women to enlighten their social roles, in any sector they choose public or domestic.

\section{Partnership Rather than Rivalism}

The ideology and gender movement should be based on a partnership framework, namely women making men as living partners or vice versa, not departing from the notion of rivalism that makes the opposite sex an enemy who will imprison the freedom of movement

27 Illich, Ivan, (1982), Gender. New York: Pantheon Books, 12.

${ }^{28}$ Muhsin, Aminah Wadud, (1994), Wanita di dalam al-Qur'an, terj. Bandung: Pustaka, 21. 
of their activities. With this perspective, the gender movement will find a harmonious relationship between rights and obligations of both men and women (check and balance), not based on gender differences but based on quality and function both in the domestic and public sectors.

It can be understood from the explanation above that, the process of women's empowerment carried out, does not mean dominating each other, not exploiting others, but the empowerment process carried out in democratic ways. Division of power based on togetherness, equality and tolerance. Women's struggles should not be trapped in the assumptions that women will face men vis a vis in radical contradictions, but will be done with mutual respect for one another. The pattern of cooperation with outside entities has become very significant in forming solid team networking to achieve the true value of success.

Besides that, the process of understanding the status of equality (egalitarianism, equality) needs to be continuously socialized for women and men, where sexual distinction no longer has implications for the existence of discrimination against the mastery of strategic accesses. For this reason, early women's empowerment should be focused on (1) strengthening women's internal psychological themselves. Are women now aware of their potential and know what they want. (2) Mastery of strategic accesses, by improving the quality of human resources. The quality of human resources as an indicator in the selection process in this competitive world. If this understanding has been absorbed in the brain cells of women, then women will occupy a very strong position in the process of bargaining while still adhering to the value of their quality and integrity.

\section{Conclusion}

Exaggerated rationalism in women's gender movements and movements as attributes of their success will lead to a feminine identity crisis, and a gender movement that bases its position on a world view that is radically alien to its cultural views and mass ideology, besides destroying the treasures of old thoughts and traditions, will also never get a satisfactory response from the mass base of their own people. And even if its existence is appreciated, even the attractiveness of the women's movement can only be heard and ignored by a group of secular elites who have lost touch with their own intellectual and spiritual universe. For this reason, formulating a format for a women's strategic movement that is conducive to accommodating various forms of problems faced by women is absolutely necessary, insofar as it does not come out of religious devices and human morality.

\section{References}

Bem, Sandra Lipsits, (1993), The lenses of Gender. New Haven: Yale University Press.

Diamond, Irene dan Gloria Leman Orenstein (ed.) (1990), Rewreaving the world; the emergence of Ecofeminism. San Francisco: Sierra Club Books.

Dzuhayatin, Sri Ruhaini, (1996), Mencari Format Gerakan Strategis Perempuan Indonesia; Sebuah catatan awal in Seminar Nasional: SEMA Adab LAIN Sunan Ampel Surabaya, 30 Januari

Fakih, Mansour, (1996), Analisis Gender dan Transformasi Sosial. Yogyakarta: Pustaka Pelajar.

Gillian, Carol, (1982), In a Different Voice. Cambridge: Harvard University.

Gordon, Suzanne, (1991), Prisoners of Men's Dream; Striking out for a New Feminine Future. Bosto: Little, Brown and Company. 
Hewlett, Sylvia Ann, (1992), When The Bough Breaks; The Cost of Neglecting our Children. Boston: Beacon Press.

Ida, Laode, (2001), Gerakan Wanita dan Dilema Budaya Lokal in Jawa Pos, 5 September.

Illich, Ivan, (1982), Gender. New York: Pantheon Books.

Kristeva, Julia, (1990), Thingking Fragmentt, Psychoanalysis, Feminism and Posmo dernism in the contemporary West. USA: University California Press.

Madjid, Nurcholish, (1996), Islam agama Kebudayaan. Jakarta: Paramadina.

Muhsin, Aminah Wadud, (1994), Wanita di dalam al-Qur'an, terj. Bandung: Pustaka.

Murata, Sachiko, (1999), The Tao of Islam; Kitab Rujukan tentang relasi Gender in Kosmologi dan Teologi Islam. Bandung: Mizan.

Naisbitt, John \& Patricia Aburdence, (1990). Megatrends 2000. New York: Avon Books.

Shihab, M. Quraisy, (2000), Gender; Pembagian Kerja Pria Wanita in Jawapos; 12. Desember

Sullivan, Norma, (1991), Gender and Politics in Indonesia in Why Gender Matter in Southeast Asian Politics, Maila Stivens (ed.) Melbourne: Monash University Press.

Thomsen, Veronika B., (1988), Why do Housewives Continue to be created in the third world too? Dalam Women the last Colony, Maria Mies (ed.) (London Zet books Ltd.), 159-166.

Widyaningsih, Wahyuni, (2001), Feminisme, ekofeminisme dan Islam Mistik in Jawa Pos. 20 Januari

Yasanti, (1995). Lika liku Buruh Perempuan. Yogyakarta: Pustaka. 